Research paper

\title{
Biomass and nutrient mass of Acacia dealbata and Eucalyptus globulus bioenergy plantations
}

\author{
Timothy J. Albaugh ${ }^{\mathrm{a},{ }^{*},}$, Rafael A. Rubilar ${ }^{\mathrm{b}}$, Chris A. Maier ${ }^{\mathrm{c}}$, Eduardo A. Acuña ${ }^{\mathrm{d}}$, \\ Rachel L. Cook ${ }^{\mathrm{e}}$ \\ a Virginia Tech Department of Forest Resources and Environmental Conservation, 228 Cheatham Hall, Blacksburg, VA 24061, USA \\ ${ }^{\mathrm{b}}$ Cooperativa de Productividad Forestal, Facultad de Ciencias Forestales, Universidad de Concepción, Victoria 631, Casilla 160-C, Concepción, Chile \\ ${ }^{\mathrm{c}}$ USDA Forest Service, 3041 Cornwallis Road, Research Triangle Park, NC, USA \\ ${ }^{\mathrm{d}}$ Facultad de Ciencias Forestales, Universidad de Concepción, Victoria 631, Casilla 160-C, Concepción, Chile \\ e Department of Forestry and Environmental Resources, Box 8008, North Carolina State University, Raleigh, NC 27695-8008, USA
}

\section{A R T I C L E I N F O}

\section{Article history:}

Received 1 July 2016

Received in revised form

12 December 2016

Accepted 24 December 2016

\section{Keywords}

Nitrogen

Phosphorus

Potassium

Calcium

Magnesium

Boron

\begin{abstract}
A B S T R A C T
We quantified biomass and nutrient accumulation of Acacia dealbata Link and Eucalyptus globulus Labill. planted at stem densities of 5000 and $15000 \mathrm{ha}^{-1}$ in a bioenergy plantation in Chile. We tested the hypotheses that species and stocking will not affect biomass or nutrient accumulation. Species and stocking did not affect biomass accumulation after five years; however, species and stocking did influence nutrient mass. A. dealbata had higher nitrogen mass than E. globulus for total ( $397 \mathrm{~kg} \mathrm{ha}^{-1}$ more, i.e., $126 \%$ higher), foliage (188 $\mathrm{kg} \mathrm{ha}^{-1}, 218 \%$ ), branch (55 $\left.\mathrm{kg} \mathrm{ha}^{-1}, 95 \%\right)$, stem (120 kg ha $\left.{ }^{-1}, 86 \%\right)$, and root (34 $\mathrm{kg} \mathrm{ha}^{-1}, 109 \%$ ) components, likely because $A$. dealbata fixes nitrogen. A. dealbata had lower calcium mass than E. globulus for branch (111 $\left.\mathrm{kg} \mathrm{ha}^{-1}, 60 \%\right)$ and stem (69 $\left.\mathrm{kg} \mathrm{ha}^{-1}, 39 \%\right)$ components. Root nitrogen and phosphorus masses and foliage, branch and root boron masses were significantly lower with a stocking density of $5000 \mathrm{ha}^{-1}$. Low stocking produced the same amount of total biomass as high stocking for both species and would be less expensive to plant. A. dealbata had higher nitrogen mass and likely increased soil nitrogen. E. globulus had high calcium mass in the stem and branches; off-site losses could be mitigated with stem-only harvests and debarking of stems in the field. Given the rainfall patterns and water availability constraints in Chile, additional criteria including water use efficiency would be required to determine the best species for bioenergy plantations in Chile.
\end{abstract}

() 2017 Elsevier Ltd. All rights reserved.

\section{Introduction}

Interest in growing plantations to produce energy has increased worldwide in recent years [1-4]. Traditionally, forest plantation management focused on solid wood products and fiber production for pulp and paper products that required relatively long rotations from 10 to 100 years depending on the species and site. Bioenergy plantations would reduce rotation length to five years or less. Agronomic crops such as grasses typically have high resource use efficiency when used as renewable feedstocks [5]. However, areas with a developed forestry industry may benefit from utilizing tree

\footnotetext{
* Corresponding author.

E-mail addresses: Tim_Albaugh@vt.edu (T.J. Albaugh), rafaelrubilar@udec.cl (R.A. Rubilar), cmaier@fs.fed.us (C.A. Maier), edacuna@udec.cl (E.A. Acuña), rlcook@ncsu.edu (R.L. Cook).
}

species that are well suited to short rotations rather than converting to bioenergy grasses or agronomic species for feedstock production. Converting to short rotation woody crop silviculture does not require land use changes, but it does require a rethinking of the employed silvicultural system. Short rotation management of nutrient and water resources and control of competing vegetation will likely differ from traditional silvicultural regimes. Consequently, there is a need to examine the sustainability of the short rotation silvicultural systems required to produce bioenergy crops from both an economic and environmental perspective. Changing forest management from long to short term will likely result in environmental changes on-site (e.g. increase in frequency and amount of fertilizer applied) and off-site (e.g. potential reductions in water availability). At the same time, these intensive plantations may permit a more efficient use of applied resources; case studies have demonstrated that more productive Eucalyptus plantations have higher resource use efficiency than less productive sites [6]. 
Managers and policymakers need objective studies to quantify the effects of changing rotation length so they may make informed decisions.

Forest productivity is a function of the amount of photosynthetic surface area and the efficiency with which solar radiation, carbon dioxide, nutrients, and water resources are converted into woody mass [7-9]. Species selection and native site resource availability set the productive potential for any species and site combination. For example, some Eucalyptus species can be extremely productive (e.g. Ref. [10]); however, selecting a Eucalyptus species that is not cold tolerant would be problematic on some sites [11,12]. The primary limiting factor for a given site may be nutrients [13-15] or water [14,16-18]. Consequently, understanding and manipulating resource availability for a specific species and site combination will be critical for managing successful bioenergy plantations. For example, fertilization may influence nutrient availability while simultaneously increasing water use efficiency by altering tree hydraulic traits $[19,20]$. Similarly, control of competing vegetation indirectly affects both nutrient and water availability for the crop species; however, controlling competing vegetation may primarily reduce water limitations in some situations [21] or nutrient limitations [22] in others. There is evidence that more uniform stands (stands where resources are equally available for all trees) may have greater light use efficiency and be more productive $[23,24]$, and that more uniform stands use resources more efficiently [6]. Stocking influences the rate of crop species site occupation where higher stocking may reduce the need for vegetation control because the competing vegetation is shaded out by the crop species. However, high stocking results in high crop species leaf area, which may induce intraspecific competition for water that results in crop tree mortality $[9,17]$.

Chile has incentives to increase the production of renewable energy sources from the forest [25]. This country has a wellestablished forest industry, is one of the top producers of wood products in the world, consistently ranking second in production in Latin America behind Brazil, and afforestation has increased in recent years [26]. Consequently, Chile is well suited to produce renewable energy from forests. However, short rotation woody crop productivity is tightly linked to available nutrient and water resources. Some current Chilean forests respond to nutrient amendments, indicating that the more intensive management required for bioenergy silviculture may increase the need for additional inputs. At the same time, there is a gradient and a seasonality in annual rainfall. More than $2 \mathrm{~m} \mathrm{yr}^{-1}$ of rain falls in the south whereas less than $40 \mathrm{~cm} \mathrm{yr}^{-1}$ of rain falls in the north. Rainfall occurs mainly in the winter, and there is a 6-month dry period during the summer [16].

A first step in understanding the nutrient and water requirements for a given bioenergy system is to quantify the nutrients accumulated in the crop in one rotation. Our interest was in quantifying biomass and nutrient accumulation after one rotation of two highly productive and fast growing species currently grown in Chile (Acacia dealbata Link and Eucalyptus globulus Labill.). This information will help determine if nutrients will become limiting and if so, what amelioration rates may be required to maintain productivity and improve efficiency of nutrient use. Specifically, we examined the following hypotheses: species, stocking, and the interaction of species and stocking will not affect total or component (foliage, branch, stem and root) biomass or nutrient (nitrogen, phosphorus, potassium, calcium, magnesium, boron) accumulation.

\section{Methods}

Our approach was to use existing stands of $A$. dealbata and
E. globulus planted at stem densities of 5000 and 15000 ha $^{-1}$ in Chile on land owned by Masisa S.A. We quantified biomass and nutrient accumulation following the approach used in Rubilar et al. [27].

\subsection{Site characteristics, experimental design and treatments}

The study site was located near Collipulli in the foothills of the Andes mountains $\left(580 \mathrm{~m}\right.$ asl) in Chile $\left(38.1238^{\circ} \mathrm{S}, 72.1053^{\circ} \mathrm{W}\right)$ (Fig. 1). The well-drained recent (8000-10000-years-old) volcanic ash (trumao) soils were $>3$ m deep and mapped as a medium, mesic Typic Haploxerand. Previous land use was a 22-year-old Pinus radiata D. Don. plantation harvested in 2009. In January 2010, the harvesting residues were removed mechanically. A pre-plant broadcast vegetation control treatment was applied using glyphosate at $3.0 \mathrm{~kg} \mathrm{ha}^{-1}$ in March 2010 and seedlings were shovel planted in July 2010. Each seedling was fertilized in October 2010 with 30 , 20 , and $3 \mathrm{~g}$ of elemental nitrogen, phosphorus and boron, respectively, applied $20 \mathrm{~cm}$ from the planting hole on the soil surface. Fertilizer sources for the nitrogen, phosphorus and boron were urea, triple superphosphate and boronatrocalcite, respectively. Additional vegetation control was completed in December 2010, April 2011 and September 2011 using $2.0 \mathrm{~kg} \mathrm{ha}^{-1}$ of glyphosate each time. Protective screens were used to avoid herbicide drift onto the plants.

A $2 \times 2$ factorial experiment designed as a randomized complete block replicated three times was established with species (E. globulus and A. dealbata) and planting density as factors. Trees were planted at 5000 and $15000 \mathrm{ha}^{-1}$ ( $5 \mathrm{~K}$ and $15 \mathrm{~K}$, respectively). Spacing was $1.41 \times 1.41 \mathrm{~m}$ and $0.816 \times 0.816 \mathrm{~m}$ in the $5 \mathrm{~K}$ and $15 \mathrm{~K}$ treatments, respectively. Plots measured $18 \times 18 \mathrm{~m}$, consequently each plot had 162 and 486 trees in the $5 \mathrm{~K}$ and $15 \mathrm{~K}$ treatments, respectively. Measurements were completed on the central 30 trees in each plot, which resulted in measurement plot sizes of $8.5 \times 7.1 \mathrm{~m}$ and $4.9 \times 4.9 \mathrm{~m}$ for the $5 \mathrm{~K}$ and $15 \mathrm{~K}$ treatments, respectively.

Meteorological data were available from a weather station located $15 \mathrm{~km}$ from the site. Rainfall was 1937, 1837, 1342, 2217, and $1457 \mathrm{~mm}$ in years 2011, 2012, 2013, 2014, and 2015, respectively. Over the five year period, mean annual temperature was $7.7^{\circ} \mathrm{C}$, with minimum and maximum monthly mean temperatures of $2.5{ }^{\circ} \mathrm{C}$ and $15.2{ }^{\circ} \mathrm{C}$ in July and January, respectively. The annual pattern of rainfall at the site was typical of that found in Chile with low rainfall, high vapor pressure deficit and high temperature in the summer and high rainfall, low vapor pressure deficit and low temperatures in winter (Table 1 ).

\subsection{Stand measurements and biomass sampling}

In February 2015, individual tree height $(H)$, root collar diameter at $0.1 \mathrm{~m}$ height (RCD), and diameter at $1.3 \mathrm{~m}$ height (D) were measured on all living trees in the measurement plot. Volume was estimated using equations from the literature [28] and [29].

$\mathrm{V}=0.3458 \times(\mathrm{D} / 1000) \times(\mathrm{D} / 1000) \times \mathrm{H}$ for A.dealbata and

$\mathrm{V}=0.00003 \times\left((\mathrm{D} / 10)^{1.8281}\right) \times\left(\mathrm{H}^{1.17322}\right)$ for E.globulus

where $\mathrm{V}$ was individual tree volume in cubic meters, D was in millimeters and $\mathrm{H}$ was in meters. Basal area and volume were calculated for each tree, summed to a plot level, and scaled to an area basis.

Biomass regressions were developed to estimate component (foliage, branch, stem and root) biomass across all treatments from 


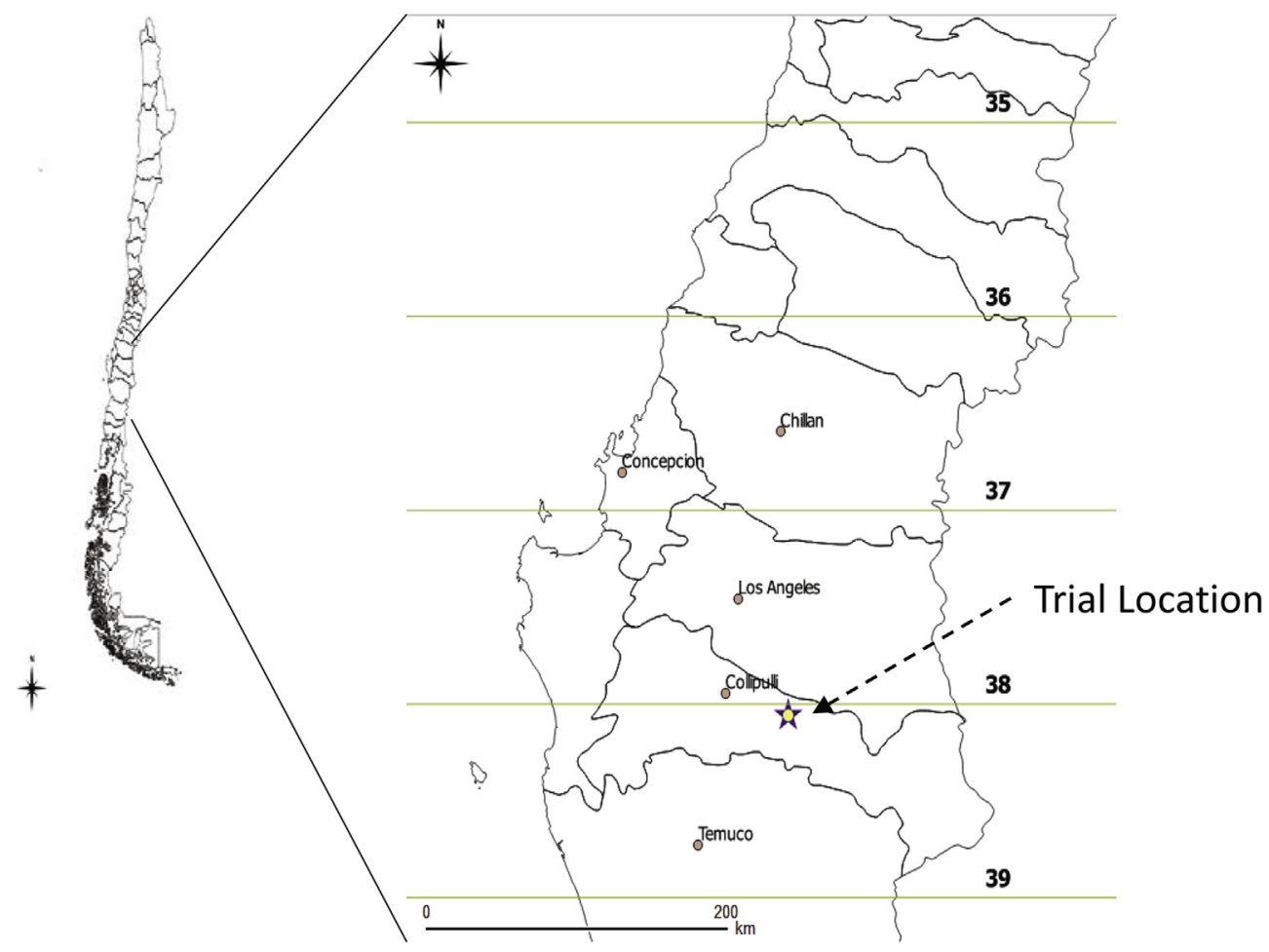

Fig. 1. Location where Acacia dealbata and Eucalyptus globulus were planted at stocking densities of 5000 and 15000 ha ${ }^{-1}$ in Chile and measured five years after planting.

Table 1

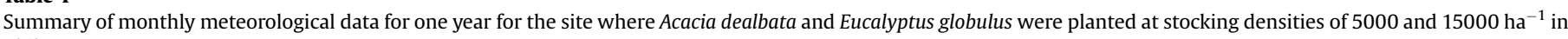
Chile.

\begin{tabular}{|c|c|c|c|c|c|c|c|c|}
\hline \multirow[t]{3}{*}{ Month } & \multirow[t]{3}{*}{ Year } & \multirow{3}{*}{$\begin{array}{l}\text { Precipitation } \\
\frac{\mathrm{mm} \mathrm{mo}^{-1}}{}\end{array}$} & \multirow{3}{*}{$\begin{array}{l}\text { Relative humidity } \\
\%\end{array}$} & \multicolumn{3}{|c|}{ Temperature } & \multirow{3}{*}{$\begin{array}{l}\text { Photosynthetically active radiation } \\
\overline{\left(\mathrm{MJ} \mathrm{m}^{2} \mathrm{~d}^{-1}\right)}\end{array}$} & \multirow{3}{*}{$\begin{array}{l}\text { Vapor pressure deficit } \\
(\mathrm{KPa})\end{array}$} \\
\hline & & & & Minimum & Maximum & Mean & & \\
\hline & & & & \multicolumn{3}{|l|}{${ }^{\circ} \mathrm{C}$} & & \\
\hline July & 2015 & 349 & 92 & -2.7 & 16.3 & 7.3 & 1.6 & 0.9 \\
\hline August & 2015 & 309 & 88 & 0.2 & 19.6 & 9.0 & 2.7 & 1.1 \\
\hline September & 2015 & 121 & 81 & -1.2 & 26.1 & 9.3 & 4.2 & 1.6 \\
\hline October & 2015 & 91 & 74 & 2.2 & 24.5 & 11.8 & 7.0 & 1.5 \\
\hline November & 2015 & 31 & 74 & -12.8 & 28.4 & 14.2 & 8.2 & 1.9 \\
\hline December & 2015 & 49 & 67 & 6.2 & 33.7 & 16.9 & 11.4 & 2.5 \\
\hline January & 2016 & 18 & 63 & 9.9 & 36.8 & 20.2 & 9.9 & 3.0 \\
\hline February & 2016 & 0 & 64 & 7.8 & 37.6 & 18.3 & 8.8 & 3.1 \\
\hline March & 2016 & 23 & 64 & 5.5 & 33.6 & 17.7 & 7.2 & 2.5 \\
\hline April & 2016 & 117 & 79 & 3.8 & 24.8 & 11.7 & 6.4 & 1.5 \\
\hline May & 2016 & 23 & 88 & 4.3 & 20.3 & 12.3 & 7.8 & 1.2 \\
\hline June & 2016 & 120 & 90 & -3.3 & 17.7 & 7.7 & 1.5 & 1.0 \\
\hline
\end{tabular}

destructively sampled trees. We included trees from two sites, our site and another site near Yumbel, Chile, with a sandy soil where the same experimental design had been installed using the same species (and one additional species, a Populus spp. clone) and stocking levels. The additional trees from the other site improved our ability to estimate component biomass for both sites by increasing the number of trees included in our biomass regressions. We tested for site, species and stocking differences in the regression models to adjust for these factors if the factors had a significant effect on a particular relationship (see below for additional information on statistical analyses completed). For the aboveground components, 92 trees were destructively sampled in the treatment plot but outside of the measurement plot. Twenty-five of the harvested trees were from our site, i.e., $13 \mathrm{~A}$. dealbata and $12 \mathrm{E}$. globulus trees were sampled. The remaining trees came from the other site. For the root component, we excavated the root system for 24 of the
92 trees sampled for aboveground components. Twelve of the root excavations were at our site and 12 were from the other site.

Harvested trees were selected to cover the range in height and diameter of the measured trees. We chose trees that were undamaged with a full set of neighbors (living trees in the eight adjacent planting spots) when possible. Selected trees were measured for H, RCD and D and cut at the ground line. Twenty leaves were selected from throughout the crown for nutrient analysis. All branches were cut from the stem. Foliage and branch material were separated in the field (for small trees) or after drying (to facilitate separation for the small Acacia leaves). Tencentimeter-long discs were cut from the stem at the base, at $1.3 \mathrm{~m}$ up the stem and halfway between the top of the tree and the base of the live crown. The fresh weight of the stem discs and the remaining stem sections were recorded in the field. The remaining stem sections were left in the field and their dry weight was 
estimated from the dry to fresh weight ratios of the stem discs. Coarse roots ( $>2 \mathrm{~mm}$ diameter) were excavated from $1 \times 1 \mathrm{~m}^{2}$ pits centered on each stump to a depth of $50 \mathrm{~cm}$. If a recognizable tap root extended below $50 \mathrm{~cm}$, this root was extracted and included in the root sample. All samples were dried at $65{ }^{\circ} \mathrm{C}$ to a constant weight. Representative samples of branch and root material were selected from the dried material for nutrient analysis. The stem discs were used for nutrient analysis. The foliage, stem, branch and root samples were ground to pass through a $1 \mathrm{~mm}$ screen and analyzed for nitrogen, phosphorus, potassium, calcium, magnesium and boron. Laboratory analyses followed the methods specified in Sadzawka et al. [30]. Nitrogen was determined colorimetrically after Kjeldahl wet digestion. Phosphorus, potassium, calcium, magnesium and boron were dry digested at $500{ }^{\circ} \mathrm{C}$ and diluted in $\mathrm{HCl}$. After digestion, phosphorus and boron were determined colorimetrically, and potassium, calcium, magnesium were determined by atomic absorption spectrophotometry.

\subsection{Statistical analyses}

A general linear model was used to develop individual tree foliage, branch, stem, and root biomass regression equations [31]. Plant components (foliage, branch, stem, and root) were the dependent variables, and site, species, stocking, and tree dimensional measurements were independent variables. The general model form was

\section{$\mathrm{C}=($ VE SI SP ST $)$}

where $\mathrm{C}$ was component biomass (foliage, branch, stem, root), VE was estimated stem volume $\left(D^{2} \mathrm{H}\right.$ and $(\mathrm{RCD})^{2} \mathrm{H}$ from the dimensional measurements), SI was site, SP was species and ST was stocking. All combination of interactions were included in the full model. Site, species and stocking were treated as categorical variables. We compared $\mathrm{D}^{2} \mathrm{H}$ and (RCD) ${ }^{2} \mathrm{H}$ models and selected the model with the highest $\mathrm{R}^{2}$. If heteroscedasticity was evident in the residuals, we used a natural logarithmic transformation. Nonsignificant independent variables were removed from the model until all independent variables in the model were significant. If multiple stems emanated from the same root system, we used the largest (based on diameter) stem in the models to estimate root mass. If data were log transformed, we used the Baskerville adjustment when converting to true scale to adjust for bias [32]. We calculated component (foliage, branch, stem and root) nutrient (nitrogen, phosphorus, potassium, calcium, magnesium and boron) mass as

\section{$\mathrm{NCM}=\mathrm{NUTCONC} *$ COMPMASS}

where NCM was nutrient component mass, NUTCONC was the concentration for the given nutrient (nitrogen, phosphorus, potassium, calcium, magnesium and boron) and COMPMASS was the mass of the component of interest (foliage, branch, stem and root). Total biomass and nutrient mass were the sum of the component biomass and nutrient masses, respectively. A linear mixed model [31] was used to examine our hypotheses regarding stocking and species effects on tree and stand metrics, component nutrient concentration, and component and total biomass and nutrient mass using

\section{$\mathrm{DEPVAR}=\mathrm{ST} \mathrm{SPST} * \mathrm{SP}$}

where block was a random effect, DEPVAR was the dependent variable (DBH, RCD, H, basal area, volume, density, total mass, foliage mass, stem mass, branch mass, root mass, and nitrogen, phosphorus potassium, calcium, magnesium and boron concentrations and component masses), and ST and SP were fixed effects for stocking and species, respectively, and treated as categorical variables. All statistical tests were evaluated with alpha $=0.05$.

\section{Results}

Site, species and stocking significantly influenced the stem and root biomass regressions (Table 2). Site significantly influenced the foliage regression, and stocking significantly influenced the branch regression.

No species or species by stocking interaction effects were significant for stand characteristics or biomass after five years. The stem component represented the highest portion of total mass for all species and stocking combinations (Fig. 2). Lower stocking significantly increased diameter at breast height by $2.0 \mathrm{~cm}(35 \%)$, root collar diameter by $2.9 \mathrm{~cm}(45 \%)$ and height by $1.0 \mathrm{~m}(13 \%)$ (Table 3). After five years of growth, considerable mortality was observed, such that only 3200 and 8100 stems remained in the $5 \mathrm{~K}$ and $15 \mathrm{~K}$ initial stocking treatments, respectively.

A. dealbata had significantly higher nitrogen concentrations than E. globulus for all plant components [foliage (136\%), branch (75\%), stem (75\%), root (97\%)] (Table 4). However, A. dealbata had significantly lower calcium concentrations than E. globulus for branch (66\%), stem (43\%) and root (44\%) components. A. dealbata also had significantly lower phosphorous (27\%) and magnesium (43\%) concentrations in the stem compared with E. globulus. Boron concentrations were significantly reduced in the $5 \mathrm{~K}$ treatment for foliage (60\%) and branch (52\%) when compared to the $15 \mathrm{~K}$ treatment. There were no significant species by stocking effects for component nutrient concentrations.

No significant stocking or species by stocking effects were found for total nutrient mass for any of the elements examined; however, there were significant species main effects. Specifically, the total nitrogen mass in A. dealbata was $397 \mathrm{~kg} \mathrm{ha}^{-1}$ (126\%) higher than that measured in E. globulus, and the total calcium mass in A. dealbata was $200 \mathrm{~kg} \mathrm{ha}^{-1}(40 \%)$ lower than that found in E. globulus (Table 5 and Fig. 3). The nitrogen mass in A. dealbata was significantly higher than that measured in E. globulus for foliage (188 kg ha $\left.{ }^{-1}, 218 \%\right)$, branch (55 $\left.\mathrm{kg} \mathrm{ha}^{-1}, 95 \%\right)$, stem (120 kg ha ${ }^{-1}$, $86 \%$ ), and root (34 $\mathrm{kg} \mathrm{ha}^{-1}, 109 \%$ ) components. The calcium mass in A. dealbata was less than that in E. globulus for branch $\left(111 \mathrm{~kg} \mathrm{ha}^{-1}\right.$, $60 \%$ ) and stem (69 $\mathrm{kg} \mathrm{ha}^{-1}, 39 \%$ ) components. However, the boron mass was higher in A. dealbata roots $\left(0.02 \mathrm{~kg} \mathrm{ha}^{-1}, 30 \%\right)$ than in E. globulus roots. The boron mass was lower in the $5 \mathrm{~K}$ treatment than in the $15 \mathrm{~K}$ treatment for foliage $\left(0.15 \mathrm{~kg} \mathrm{ha}^{-1}, 74 \%\right)$, branch $\left(0.09 \mathrm{~kg} \mathrm{ha}^{-1}, 68 \%\right)$ and root $\left(0.04 \mathrm{~kg} \mathrm{ha}^{-1}, 37 \%\right)$ components. Root nitrogen and phosphorus masses were significantly lower in the $5 \mathrm{~K}$ treatment ( $19 \mathrm{~kg} \mathrm{ha}^{-1}, 33 \%$, and $6 \mathrm{~kg} \mathrm{ha}^{-1}, 23 \%$, respectively) than in the $15 \mathrm{~K}$ treatment. There was a significant species by stocking interaction for potassium, calcium and magnesium in the roots. Specifically, the masses of these elements were similar between the different stocking levels for A. dealbata, but in E. globulus, the root mass of these elements in the $15 \mathrm{~K}$ treatment was more than twice that of the potassium, calcium and magnesium masses in the $5 \mathrm{~K}$ treatment.

\section{Discussion}

We accepted our hypothesis that species and stocking would not affect total, foliage, stem, branch and root biomass because we did not detect significant stocking or species effects for these variables. Consequently, when managing a stand for biomass production on a five-year rotation, A. dealbata and E. globulus will produce approximately the same amount of biomass material. However, 
Table 2

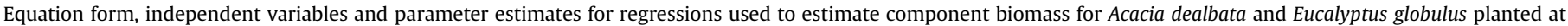
stocking densities of 5000 and $15000 \mathrm{ha}^{-1}$ in Chile and measured five years after planting.

\begin{tabular}{|c|c|c|c|c|c|c|}
\hline Dependent variable & Species & Initial stocking & Independent variable & B1 & B0 & MSE \\
\hline \multirow[t]{4}{*}{ Foliage mass } & $\mathrm{AD}$ & 5000 & d2hlog & 0.799872 & 9.310965 & 0.488241 \\
\hline & $\mathrm{AD}$ & 15000 & d2hlog & 0.799872 & 9.310965 & 0.488241 \\
\hline & EG & 5000 & d2hlog & 0.799872 & 9.310965 & 0.488241 \\
\hline & EG & 15000 & d2hlog & 0.799872 & 9.310965 & 0.488241 \\
\hline \multirow[t]{4}{*}{ Branch mass } & $\mathrm{AD}$ & 5000 & r2hlog & 0.814304 & 9.405796 & 1.069368 \\
\hline & $\mathrm{AD}$ & 15000 & r2hlog & 0.814304 & 9.445973 & 1.069368 \\
\hline & EG & 5000 & r2hlog & 0.814304 & 9.405796 & 1.069368 \\
\hline & EG & 15000 & r2hlog & 0.814304 & 9.445973 & 1.069368 \\
\hline \multirow[t]{4}{*}{ Stem mass } & $\mathrm{AD}$ & 5000 & r2hlog & 1.068731 & 11.8867 & 0.300841 \\
\hline & $\mathrm{AD}$ & 15000 & r2hlog & 1.062239 & 11.87397 & 0.300841 \\
\hline & EG & 5000 & r2hlog & 1.068731 & 11.99798 & 0.300841 \\
\hline & EG & 15000 & r2hlog & 1.062239 & 12.01482 & 0.300841 \\
\hline \multirow[t]{4}{*}{ Root mass } & $\mathrm{AD}$ & 5000 & rm2hmlog & 0.74324 & 9.568309 & 0.082798 \\
\hline & $A D$ & 15000 & $\mathrm{rm} 2 \mathrm{hmlog}$ & 0.74324 & 9.554291 & 0.082798 \\
\hline & EG & 5000 & $\mathrm{rm} 2 \mathrm{hmlog}$ & 0.74324 & 9.561507 & 0.082798 \\
\hline & EG & 15000 & $\mathrm{rm} 2 \mathrm{hmlog}$ & 0.74324 & 9.547489 & 0.082798 \\
\hline
\end{tabular}

where, $\mathrm{AD}=$ Acacia dealbata and $\mathrm{EG}=$ Eucalyptus globulus.

Initial stocking units are ha ${ }^{-1}$.

$\mathrm{d} 2 \mathrm{hlog}=$ natural log of diameter at breast height squared times height.

r2hlog = natural log of root collar diameter squared times height.

rm2hmlog = natural log of maximum root collar diameter of all stems

growing from the coppice stump squared times maximum height of all stems

growing from the coppice stump.

Diameter at breast height, root collar diameter and height are expressed as $\mathrm{m}$.

$\mathrm{B} 0$ and $\mathrm{B} 1$ are parameter estimates.

MSE is the mean square error of the regression.

Output is at the individual tree scale in $\mathrm{g}$ for each component.

Equation form:

Dependent variable $=\exp [(\text { independent variable*B1 })+B 0]^{*} \exp (\mathrm{MSE} / 2)$

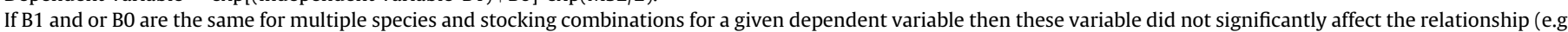
for foliage mass B0 and B1 are the same for all species and stocking combination because species and stocking did not influence the foliage mass relationship).

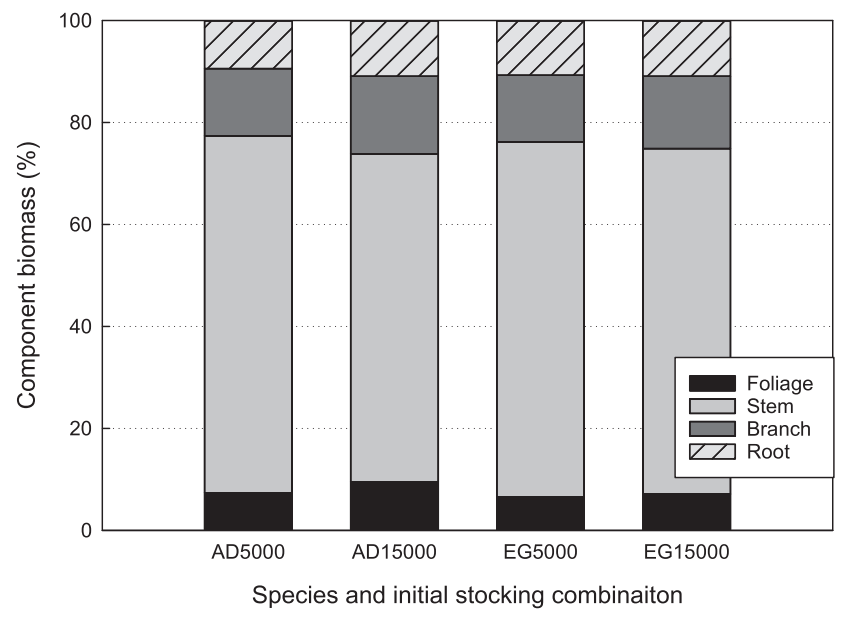

Fig. 2. Biomass accumulated in foliage, stem, branch and root measured five years after planting as a percentage of total biomass for Acacia dealbata (AD) and Eucalyptus globulus (EG) planted at stocking densities of 5000 and $15000 \mathrm{ha}^{-1}$ in Chile.

since there was no difference in the biomass produced after five years at these stocking levels, from an economic perspective, it would be less expensive to plant at a stem density of $5000 \mathrm{ha}^{-1}$ rather than $15000 \mathrm{ha}^{-1}$. Additionally, the overall bark to wood ratio would likely be less when planting at a stem density of $5000 \mathrm{ha}^{-1}$, which would also increase stand value. It is possible that our experimental design which included only three replications may have permitted us to accept this hypothesis when we should have rejected it. The generally high p values for species (Table 3) do not support this alternative argument for our species test. However, it is likely that the rotation length of five years influenced our examination of this hypothesis for stocking. Had we completed our assessment in a shorter time period (e.g. after three years), it is possible that differences in biomass accumulation due to stocking would have been evident. Given our root sampling protocol, it was somewhat surprising that we did not detect a difference in root mass for the different stocking levels. We excavated the roots from a $1 \mathrm{~m}^{2}$ pit centered on the tree stump. In the $5 \mathrm{~K}$ treatment, the spacing was $1.4 \times 1.4 \mathrm{~m}$; therefore, the sample pit represented somewhat less than the area allocated to the tree at planting. In the $15 \mathrm{~K}$ treatment, spacing was $0.82 \times 0.82 \mathrm{~m}$; therefore, the sample pit was somewhat larger than the area allocated to the tree at planting. It is likely that the stand had reached a level of root closure where roots had fully explored the soil, and the surface area of our sample pit was immaterial.

We rejected our hypothesis that species would not affect total nitrogen and calcium mass, foliage nitrogen mass, branch nitrogen and calcium mass, stem nitrogen and calcium mass and root nitrogen, calcium, magnesium and boron mass. For all cases where the nitrogen and boron masses were affected by species, $A$. dealbata had a higher nutrient mass than E. globulus, whereas when phosphorus, calcium and magnesium were affected by species, E. globulus had a higher nutrient mass than A. dealbata. As noted, there were no significant species differences for total or component biomass accumulation; consequently, the observed differences in nutrient mass were driven by differences in nutrient concentration. It is not surprising that $A$. dealbata would have higher nitrogen concentrations and ultimately nitrogen masses compared with E. globulus given that it is a nitrogen fixing plant [33]. A. dealbata can produce up to $80 \%$ (reported range from 42 to $80 \%$ ) of its nitrogen mass through nitrogen fixing [34,35]. If we use the middle of the range (60\%) to estimate the amount of nitrogen mass fixed by A. dealbata in our study, the amount of nitrogen accumulated in A. dealbata that was not fixed by the plant is approximately 
Table 3

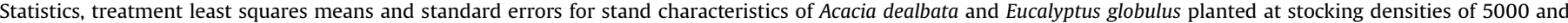
$15000 \mathrm{ha}^{-1}$ in Chile. Bold values indicate $\mathrm{p}$ values less than 0.05 .

\begin{tabular}{|c|c|c|c|c|c|c|c|c|}
\hline \multirow[t]{3}{*}{ Variable } & \multicolumn{3}{|c|}{ Statistics ( $\mathrm{p}$ values) } & \multicolumn{4}{|l|}{ Means } & \multirow[t]{3}{*}{ Standard error } \\
\hline & \multirow[t]{2}{*}{ Species } & \multirow[t]{2}{*}{ Stocking } & \multirow[t]{2}{*}{ Species $\mathrm{x}$ stocking } & \multicolumn{2}{|l|}{ Species } & \multicolumn{2}{|c|}{ Stocking } & \\
\hline & & & & Acacia & Eucalyptus & 5000 & 15000 & \\
\hline Diameter at breast height $(\mathrm{cm})$ & 0.638 & 0.003 & 0.719 & 6.7 & 6.5 & 7.6 & 5.6 & 0.3 \\
\hline Root collar diameter $(\mathrm{cm})$ & 0.059 & 0.000 & 0.248 & 7.3 & 8.1 & 9.2 & 6.3 & 0.3 \\
\hline Height $(\mathrm{m})$ & 0.925 & 0.044 & 0.072 & 8.4 & 8.4 & 8.9 & 7.9 & 0.5 \\
\hline Basal area $\left(\mathrm{m}^{2} \mathrm{ha}^{-1}\right)$ & 0.391 & 0.114 & 0.797 & 22.7 & 19.2 & 17.5 & 24.4 & 1.9 \\
\hline Volume $\left(\mathrm{m}^{3} \mathrm{ha}^{-1}\right)$ & 0.155 & 0.313 & 0.645 & 115.9 & 75.9 & 82.3 & 109.4 & 13.2 \\
\hline Density (tree ha ${ }^{-1}$ ) & 0.581 & 0.000 & 0.874 & 5848 & 5458 & 3214 & 8093 & 565 \\
\hline Total mass $\left(\mathrm{Mg} \mathrm{ha}^{-1}\right)$ & 0.679 & 0.268 & 0.328 & 100 & 91.1 & 83.3 & 108 & 11.5 \\
\hline Foliage mass $\left(\mathrm{Mg} \mathrm{ha}^{-1}\right)$ & 0.206 & 0.094 & 0.692 & 8.4 & 6.3 & 5.9 & 8.9 & 0.9 \\
\hline Stem mass $\left(\mathrm{Mg} \mathrm{ha}^{-1}\right)$ & 0.761 & 0.404 & 0.297 & 67.0 & 62.4 & 58.2 & 71.2 & 8.4 \\
\hline Branch mass ( $\left.\mathrm{Mg} \mathrm{ha}^{-1}\right)$ & 0.518 & 0.086 & 0.355 & 14.2 & 12.6 & 11.0 & 15.8 & 1.4 \\
\hline Root mass ( $\left.\mathrm{Mg} \mathrm{ha}^{-1}\right)$ & 0.876 & 0.103 & 0.390 & 10.1 & 9.9 & 8.3 & 11.7 & 0.9 \\
\hline
\end{tabular}

Table 4

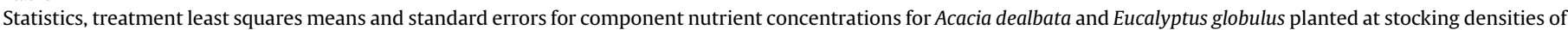
5000 and $15000 \mathrm{ha}^{-1}$ in Chile. Bold values indicate $\mathrm{p}$ values less than 0.05 .

\begin{tabular}{|c|c|c|c|c|c|c|c|c|}
\hline \multirow[t]{3}{*}{ Nutrient } & \multicolumn{3}{|c|}{ Statistics (p values) } & \multicolumn{4}{|l|}{ Means } & \multirow[t]{3}{*}{ Standard error } \\
\hline & \multirow[t]{2}{*}{ Species } & \multirow[t]{2}{*}{ Stocking } & \multirow[t]{2}{*}{ Species $\mathrm{x}$ stocking } & \multicolumn{2}{|c|}{ Species } & \multicolumn{2}{|c|}{ Stocking } & \\
\hline & & & & Acacia & Eucalyptus & 5000 & 15000 & \\
\hline \multicolumn{9}{|l|}{ Foliage } \\
\hline Nitrogen $\left(\mathrm{mg} \mathrm{g}^{-1}\right)$ & 0.000 & 0.204 & 0.232 & 32.0 & 13.5 & 21.9 & 23.5 & 1.0 \\
\hline Phosphorus ( $\mathrm{mg} \mathrm{g}^{-1}$ ) & 0.336 & 0.971 & 0.859 & 1.03 & 0.86 & 0.94 & 0.95 & 0.09 \\
\hline Potassium ( $\left.\mathrm{mg} \mathrm{g}^{-1}\right)$ & 0.184 & 0.555 & 0.698 & 6.68 & 5.12 & 6.22 & 5.58 & 0.60 \\
\hline Calcium $\left(\mathrm{mg} \mathrm{g}^{-1}\right)$ & 0.440 & 0.406 & 0.281 & 10.5 & 13.5 & 10.3 & 13.6 & 2.1 \\
\hline Magnesium ( $\left.\mathrm{mg} \mathrm{g}^{-1}\right)$ & 0.431 & 0.702 & 0.282 & 2.21 & 1.87 & 1.96 & 2.12 & 0.24 \\
\hline Boron $\left(\mu \mathrm{g} \mathrm{g}^{-1}\right)$ & 0.986 & 0.034 & 0.759 & 16.6 & 16.7 & 9.5 & 23.8 & 2.7 \\
\hline \multicolumn{9}{|l|}{ Branch } \\
\hline Nitrogen $\left(\mathrm{mg} \mathrm{g}^{-1}\right)$ & 0.002 & 0.249 & 0.837 & 7.90 & 4.53 & 5.82 & 6.61 & 0.33 \\
\hline Phosphorus ( $\mathrm{mg} \mathrm{g}^{-1}$ ) & 0.072 & 0.268 & 0.658 & 0.37 & 0.53 & 0.49 & 0.40 & 0.05 \\
\hline Potassium $\left(\mathrm{mg} \mathrm{g}^{-1}\right)$ & 0.522 & 0.231 & 0.765 & 4.05 & 4.42 & 4.61 & 3.86 & 0.39 \\
\hline Calcium $\left(\mathrm{mg} \mathrm{g}^{-1}\right)$ & 0.007 & 0.416 & 0.434 & 5.25 & 15.5 & 11.5 & 9.25 & 2.05 \\
\hline Magnesium ( $\left.\mathrm{mg} \mathrm{g}^{-1}\right)$ & 0.584 & 0.913 & 0.561 & 1.46 & 1.25 & 1.38 & 1.33 & 0.23 \\
\hline Boron $\left(\mu \mathrm{g} \mathrm{g}^{-1}\right)$ & 0.086 & 0.029 & 0.311 & 4.9 & 8.2 & 4.2 & 8.9 & 0.9 \\
\hline \multicolumn{9}{|l|}{ Stem } \\
\hline Nitrogen $\left(\mathrm{mg} \mathrm{g}^{-1}\right)$ & 0.001 & 0.283 & 0.660 & 3.94 & 2.24 & 2.93 & 3.26 & 0.22 \\
\hline Phosphorus (mg g ${ }^{-1}$ ) & 0.044 & 0.058 & 0.191 & 0.20 & 0.27 & 0.20 & 0.27 & 0.02 \\
\hline Potassium $\left(\mathrm{mg} \mathrm{g}^{-1}\right)$ & 0.083 & 0.691 & 0.420 & 2.20 & 1.77 & 1.94 & 2.03 & 0.11 \\
\hline Calcium $\left(\mathrm{mg} \mathrm{g}^{-1}\right)$ & 0.000 & 0.355 & 0.766 & 1.61 & 2.83 & 2.17 & 2.27 & 0.09 \\
\hline Magnesium ( $\left.\mathrm{mg} \mathrm{g}^{-1}\right)$ & 0.001 & 0.403 & 0.740 & 0.34 & 0.61 & 0.46 & 0.49 & 0.03 \\
\hline Boron $\left(\mu \mathrm{g} \mathrm{g}^{-1}\right)$ & 0.923 & 0.821 & 0.985 & 6.9 & 7.0 & 7.1 & 6.8 & 1.0 \\
\hline \multicolumn{9}{|l|}{ Root } \\
\hline Nitrogen $\left(\mathrm{mg} \mathrm{g}^{-1}\right)$ & 0.008 & 0.632 & 0.658 & 6.52 & 3.32 & 4.71 & 5.12 & 0.53 \\
\hline Phosphorus ( $\mathrm{mg} \mathrm{g}^{-1}$ ) & 0.469 & 0.884 & 0.996 & 0.49 & 0.58 & 0.53 & 0.55 & 0.09 \\
\hline Potassium $\left(\mathrm{mg} \mathrm{g}^{-1}\right)$ & 0.725 & 0.365 & 0.163 & 2.16 & 2.27 & 2.37 & 2.06 & 0.24 \\
\hline Calcium $\left(\mathrm{mg} \mathrm{g}^{-1}\right)$ & 0.033 & 0.161 & 0.228 & 2.82 & 5.00 & 3.28 & 4.54 & 0.40 \\
\hline Magnesium ( $\left.\mathrm{mg} \mathrm{g}^{-1}\right)$ & 0.058 & 0.978 & 0.521 & 0.62 & 1.13 & 0.87 & 0.88 & 0.18 \\
\hline Boron $\left(\mu \mathrm{g} \mathrm{g}^{-1}\right)$ & 0.216 & 0.646 & 0.982 & 10.8 & 8.4 & 9.2 & 10.0 & 1.0 \\
\hline
\end{tabular}

$284 \mathrm{~kg} \mathrm{ha}^{-1}$ and similar to the $314 \mathrm{~kg} \mathrm{ha}^{-1}$ nitrogen mass found for E. globulus. At the same time that $A$. dealbata increases nitrogen in the plant, it may also increase nitrogen in the soil. This phenomenon was observed in an earlier study that found an increase in total soil nitrogen up to $589 \mathrm{~kg} \mathrm{ha}^{-1}$ in five-year-old $A$. dealbata plantations [34]. Consequently, even with higher total nitrogen mass in A. dealbata stands, there would be little concern that nitrogen would become limiting after successive removals when using a bioenergy plantation management scheme.

However, this may not be the case for the other elements where significant species differences were found. Boron deficiencies have been identified for Eucalyptus and Acacia species in Chile and other parts of the world [36]. Even so, correcting a boron deficiency is relatively easy, and boron was added at this site at planting because boron deficiencies are common in the area. Both species had similar foliar boron concentrations (16.6 and $16.7 \mathrm{mg} \mathrm{g}^{-1}$ of dry leaf mass for $A$. dealbata and $E$. globulus, respectively), which were in the range of boron foliar nutrient concentrations from the literature for similar species (A. mangium, $8-43 \mathrm{mg} \mathrm{g}^{-1}$, [37]) or the genera (Eucalyptus, 15-84 $\mathrm{mg} \mathrm{g}^{-1}$, [38]). The fact that the root boron mass in A. dealbata was higher than in E. globulus is likely related to the multiplicative effect of slightly but non-significantly higher boron root concentrations and biomass in A. dealbata (Tables 3 and 4). A similar explanation is likely for the significant increase in root boron mass in the $15 \mathrm{~K}$ treatment relative to the $5 \mathrm{~K}$ treatment.

The total calcium mass in A. dealbata was significantly lower than in E. globulus. The foliage calcium mass was approximately the same for both species, but there were large differences in the 
Table 5

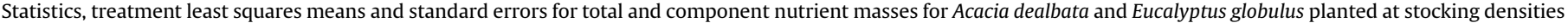
of 5000 and $15000 \mathrm{ha}^{-1}$ in Chile. Bold values indicate $\mathrm{p}$ values less than 0.05 .

\begin{tabular}{|c|c|c|c|c|c|c|c|c|}
\hline \multirow[t]{3}{*}{ Variable } & \multicolumn{3}{|c|}{ Statistics ( $p$ values) } & \multicolumn{4}{|l|}{ Means } & \multirow[t]{3}{*}{ Standard error } \\
\hline & \multirow[t]{2}{*}{ Species } & \multirow[t]{2}{*}{ Stocking } & \multirow[t]{2}{*}{ Species x stocking } & \multicolumn{2}{|l|}{ Species } & \multicolumn{2}{|c|}{ Stocking } & \\
\hline & & & & Acacia & Eucalyptus & 5000 & 15000 & \\
\hline \multicolumn{9}{|l|}{ Total nutrient mass } \\
\hline Nitrogen mass $\left(\mathrm{kg} \mathrm{ha}^{-1}\right)$ & 0.012 & 0.166 & 0.851 & 711 & 314 & 424 & 601 & 67 \\
\hline Phosphorus mass ( $\mathrm{kg} \mathrm{ha}^{-1}$ ) & 0.813 & 0.118 & 0.705 & 33 & 35 & 26 & 41 & 5 \\
\hline Potassium mass $\left(\mathrm{kg} \mathrm{ha}^{-1}\right)$ & 0.378 & 0.496 & 0.622 & 292 & 219 & 227 & 283 & 43 \\
\hline Calcium mass $\left(\mathrm{kg} \mathrm{ha}^{-1}\right)$ & 0.036 & 0.067 & 0.421 & 296 & 496 & 313 & 479 & 40 \\
\hline Magnesium mass $\left(\mathrm{kg} \mathrm{ha}^{-1}\right)$ & 0.785 & 0.182 & 0.709 & 70.2 & 75.6 & 58.8 & 87.0 & 11.6 \\
\hline Boron mass $\left(\mathrm{kg} \mathrm{ha}^{-1}\right)$ & 0.865 & 0.113 & 0.357 & 0.79 & 0.75 & 0.60 & 0.94 & 0.10 \\
\hline \multicolumn{9}{|l|}{ Foliar nutrient mass } \\
\hline Nitrogen mass $\left(\mathrm{kg} \mathrm{ha}^{-1}\right)$ & 0.014 & 0.201 & 0.634 & 275 & 87 & 142 & 220 & 36 \\
\hline Phosphorus mass ( $\mathrm{kg} \mathrm{ha}^{-1}$ ) & 0.222 & 0.310 & 0.886 & 8.9 & 5.5 & 5.9 & 8.6 & 1.5 \\
\hline Potassium mass $\left(\mathrm{kg} \mathrm{ha}^{-1}\right)$ & 0.150 & 0.436 & 0.966 & 58 & 32 & 38 & 52 & 10 \\
\hline Calcium mass $\left(\mathrm{kg} \mathrm{ha}^{-1}\right)$ & 0.932 & 0.070 & 0.498 & 88 & 85 & 55 & 118 & 19 \\
\hline Magnesium mass $\left(\mathrm{kg} \mathrm{ha}^{-1}\right)$ & 0.227 & 0.181 & 0.547 & 19.3 & 11.8 & 11.4 & 19.8 & 3.9 \\
\hline Boron mass $\left(\mathrm{kg} \mathrm{ha}^{-1}\right)$ & 0.649 & 0.008 & 0.970 & 0.14 & 0.12 & 0.05 & 0.20 & 0.02 \\
\hline \multicolumn{9}{|l|}{ Branch nutrient mass } \\
\hline Nitrogen mass $\left(\mathrm{kg} \mathrm{ha}^{-1}\right)$ & 0.026 & 0.101 & 0.852 & 113 & 58 & 67 & 103 & 11 \\
\hline Phosphorus mass ( $\mathrm{kg} \mathrm{ha}^{-1}$ ) & 0.376 & 0.350 & 0.513 & 5.1 & 6.6 & 5.1 & 6.6 & 1.1 \\
\hline Potassium mass $\left(\mathrm{kg} \mathrm{ha}^{-1}\right)$ & 0.807 & 0.522 & 0.469 & 58 & 54 & 51 & 62 & 9 \\
\hline Calcium mass $\left(\mathrm{kg} \mathrm{ha}^{-1}\right)$ & 0.011 & 0.382 & 0.552 & 73 & 184 & 114 & 143 & 19 \\
\hline Magnesium mass ( $\left.\mathrm{kg} \mathrm{ha}^{-1}\right)$ & 0.372 & 0.468 & 0.909 & 21.5 & 14.8 & 15.5 & 20.8 & 3.5 \\
\hline Boron mass $\left(\mathrm{kg} \mathrm{ha}^{-1}\right)$ & 0.199 & 0.032 & 0.231 & 0.07 & 0.12 & 0.05 & 0.14 & 0.02 \\
\hline \multicolumn{9}{|l|}{ Stem nutrient mass } \\
\hline Nitrogen mass $\left(\mathrm{kg} \mathrm{ha}^{-1}\right)$ & 0.029 & 0.335 & 0.300 & 259 & 139 & 177 & 221 & 24 \\
\hline Phosphorus mass $\left(\mathrm{kg} \mathrm{ha}^{-1}\right)$ & 0.491 & 0.117 & 0.829 & 13.9 & 17.1 & 11.6 & 19.5 & 2.4 \\
\hline Potassium mass $\left(\mathrm{kg} \mathrm{ha}^{-1}\right)$ & 0.362 & 0.583 & 0.689 & 154 & 110 & 119 & 145 & 24 \\
\hline Calcium mass $\left(\mathrm{kg} \mathrm{ha}^{-1}\right)$ & 0.043 & 0.132 & 0.129 & 108 & 176 & 119 & 165 & 19 \\
\hline Magnesium mass $\left(\mathrm{kg} \mathrm{ha}^{-1}\right)$ & 0.108 & 0.209 & 0.305 & 23.6 & 38.1 & 25.4 & 36.3 & 5.1 \\
\hline Boron mass $\left(\mathrm{kg} \mathrm{ha}^{-1}\right)$ & 0.780 & 0.703 & 0.384 & 0.47 & 0.43 & 0.42 & 0.48 & 0.08 \\
\hline \multicolumn{9}{|l|}{ Root nutrient mass } \\
\hline Nitrogen mass $\left(\mathrm{kg} \mathrm{ha}^{-1}\right)$ & 0.000 & 0.000 & 0.539 & 65 & 31 & 38 & 57 & 4 \\
\hline Phosphorus mass $\left(\mathrm{kg} \mathrm{ha}^{-1}\right)$ & 0.331 & 0.015 & 0.322 & 4.8 & 5.6 & 3.9 & 6.4 & 0.8 \\
\hline Potassium mass $\left(\mathrm{kg} \mathrm{ha}^{-1}\right)$ & 0.675 & 0.125 & 0.039 & 21 & 22 & 19 & 25 & 3 \\
\hline Calcium mass $\left(\mathrm{kg} \mathrm{ha}^{-1}\right)$ & 0.005 & 0.003 & 0.016 & 27 & 50 & 26 & 52 & 3 \\
\hline Magnesium mass $\left(\mathrm{kg} \mathrm{ha}^{-1}\right)$ & 0.001 & 0.006 & 0.014 & 5.8 & 10.8 & 6.5 & 10.2 & 1.3 \\
\hline Boron mass $\left(\mathrm{kg} \mathrm{ha}^{-1}\right)$ & 0.031 & 0.003 & 0.309 & 0.11 & 0.08 & 0.07 & 0.11 & 0.01 \\
\hline
\end{tabular}

branch, stem and root components where the calcium mass measured in E. globulus was up to two times the amount of calcium measured in A. dealbata components (Table 5). If a complete tree aboveground harvest was completed, $445 \mathrm{~kg} \mathrm{ha}^{-1}$ of calcium would be removed from the E. globulus stands; more than any other element. While large calcium accumulations in Eucalyptus species have been noted in the literature, it is not clear whether there is a need for concern given the potential for frequent nutrient removals associated with bioenergy plantations. Nitrogen, phosphorus and boron deficiencies in Eucalyptus have been observed in Chile; however no mention of calcium deficiencies has been found [39]. Calcium has generally low physiological activity and may be taken up well in excess of need [40]. Harvesting is typically the main cause for nutrient loss from a site, but the effects of these nutrient removals have not been demonstrated and are uncertain [41,42]. Even with whole tree harvesting on poor sandy soils, little impact on soil nutrient and organic matter mass and subsequent biomass production have been observed [43]. Regardless that some soils in Chile have relatively high amounts of exchangeable calcium [44], incorporating measures to conserve nutrient capital on-site would likely be prudent. Given that approximately $80 \%$ of the calcium in our E. globulus stands was in the branch and stem components, leaving branches and removing bark on-site as suggested in the literature [42] would reduce net calcium removals considerably.

We rejected the hypothesis that stocking would not affect nutrient accumulation for boron in the foliage, branch and root components and for nitrogen, phosphorus, potassium, calcium and magnesium in the root components. In all cases for the root component, the $15 \mathrm{~K}$ treatment had a higher nutrient mass than the $5 \mathrm{~K}$ treatment, and for E. globulus, the higher nutrient mass was much higher in the $15 \mathrm{~K}$ treatment than in the $5 \mathrm{~K}$ treatment when compared to the increase observed with $A$. dealbata (a significant species by stocking interaction). These increases in nutrient mass are not surprising given that there were more stems (about $4800 \mathrm{ha}^{-1}$ ) in the higher stocking treatment at the time of harvest. As noted, boron is easily and readily added to plantations in the area to avoid known boron limitations. The nitrogen, phosphorus, potassium, calcium and magnesium differences were limited to the root component, and any additional nutrients accumulated with the higher stocking would remain on-site in an aboveground biomass harvest. At the same time, given that the total biomass accumulated in the two stocking treatments did not differ five years after planting, it is likely that only the lower stocking level would be used in future plantations.

Biomass accumulations in our study were similar to those reported in the literature. Total biomass accumulations of 43-109 $\mathrm{Mg} \mathrm{ha}^{-1}$, depending on site and nutritional regime, with corresponding nitrogen, phosphorus and potassium accumulations of $75-225,5-28$, and $50-240 \mathrm{~kg} \mathrm{ha}^{-1}$, respectively, were found after six years of growth for E. globulus in Australia [45]. In Chile, E. globulus grew 36.7 $\mathrm{Mg} \mathrm{ha}^{-1}$ after four years in one study [46], and $16.9 \mathrm{~m}^{3} \mathrm{ha}^{-1} \mathrm{yr}^{-1}$, which is approximately $38 \mathrm{Mg} \mathrm{ha}^{-1}$ after five years in another study [47] (7.7 $\mathrm{Mg} \mathrm{ha}^{-1} \mathrm{yr}^{-1}$ for 5 years for under bark stem production assuming $\sim 2.2 \mathrm{~m}^{3} \mathrm{Mg}^{-1}$ [48]). A. dealbata 


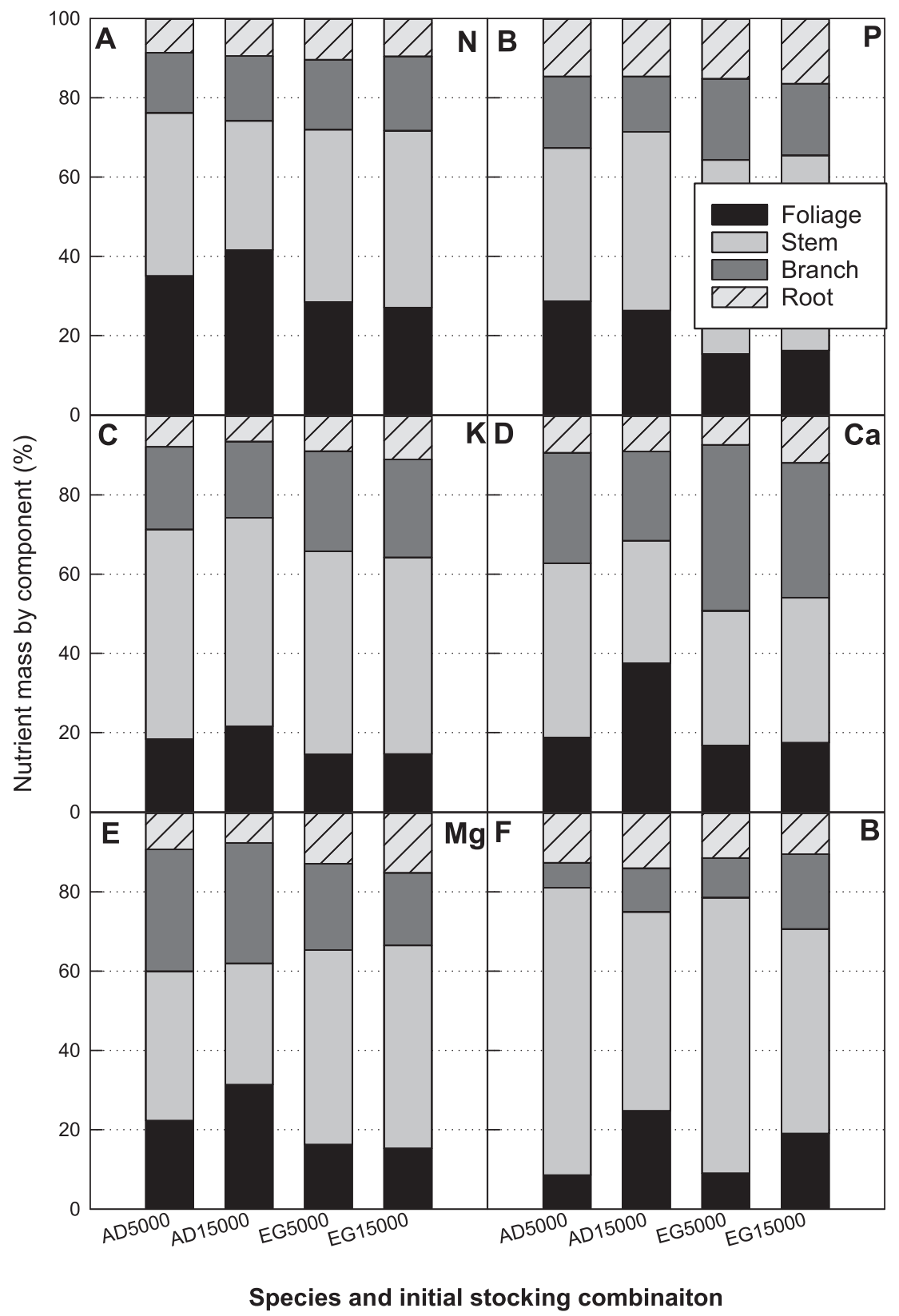

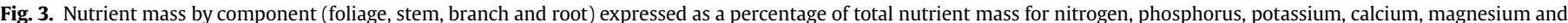

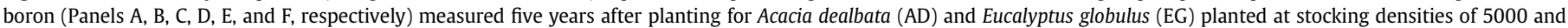
$15000 \mathrm{ha}^{-1}$ in Chile.

biomass production reports include $20.9 \mathrm{Mg} \mathrm{ha}^{-1}$ after four years in Chile [46] and a range of $15-30 \mathrm{Mg} \mathrm{ha}^{-1}$ for four- and five-year-old stands [49]. Higher productivity may have been possible, at least with E. globulus, given that the foliar nutrient concentrations would have been considered deficient or on the low end of the adequate range for eucalypts in general [50]. Foliar nutrient concentration recommendations for $A$. dealbata were not found; however it is likely that nitrogen, the primary limiting factor in most forest plantations, would not be limiting because of the nitrogen fixing ability of this species.

Our study quantified the production potential of E. globulus and A. dealbata for biomass plantations in Chile. From a total biomass production perspective, there was no significant difference between the species after five years whether the initial planting density was 5000 or $15000 \mathrm{ha}^{-1}$. Consequently, there would be an advantage to plant the lower initial stocking $\left(5000 \mathrm{ha}^{-1}\right)$ regardless of species simply to reduce initial costs. E. globulus would accumulate considerably more calcium in the stem and branches, which would likely be removed during biomass harvests, thus increasing the risk of inducing calcium deficiencies in subsequent rotations. However, this risk may be small and may be managed by leaving the branches and debarking the stems in the field [41,42]. Although A. dealbata is known to be invasive in Chile and is already widespread, as a nitrogen fixer, it would likely improve soil nutrition over time [33]. Given the rainfall patterns (Table 1) and water availability constraints in Chile [16,51], additional criteria including water use efficiency of the species would be required to fully determine the best species for biomass production. Additionally, 
other research has shown that for E. globulus and another Acacia species (A. mearnsii), planting the species together produces more biomass than when either is grown alone and consequently, rather than selecting one species or the other, a mix of species may be the best alternative [52].

\section{Acknowledgements}

We gratefully acknowledge the support provided by the Forest Productivity Cooperative and especially Masisa S.A. for their role in providing the study site. We appreciate the support of the Department of Forest Resources and Environmental Conservation at Virginia Polytechnic Institute and State University, the Departamento de Silvicultura, Facultad de Ciencias Forestales, Universidad de Concepción and the Department of Forestry and Environmental Resources at North Carolina State University. Funding for this work was provided in part by the Virginia Agricultural Experiment Station and the McIntire-Stennis Program of the National Institute of Food and Agriculture, United States Department of Agriculture. This work was supported by the Chilean National Commission for Scientific and Technological Research with FONDECYT Project Grant \#1140482. We thank all those who helped complete the field work and to process the biomass samples especially Leonardo Muñoz, Juan Espinoza, Yuri Burgos, Marco Yañez, Viviana Muñoz and Pablo Mena. The use of trade names in this paper does not imply endorsement by the associated agencies of the products named, nor criticism of similar ones not mentioned.

\section{References}

[1] L. Wright, Worldwide commercial development of bioenergy with focus on energy crop-based projects, Biomass Bioenergy 30 (2006) 706-714.

[2] H. Grunewald, B.K.V. Brandt, B.U. Schneider, O. Bens, G. Kendzia, R.F. Huttl, Agroforestry systems for the production of woody biomass for energy transformation purposes, Ecol. Eng. 29 (2007) 319-328.

[3] R. Baettig, M.A. Yanez, M.A. Albornoz, Short rotation woody crops of hybrid poplars for bioenergy in Chile: State of the art, Bosque 31 (2) (2010) 89-99.

[4] J.R. Bartle, A. Abadi, Toward sustainable production of second generation bioenergy feedstocks, Energy Fuels 24 (1) (2010) 2-9.

[5] J.S. King, R. Ceulemans, J.M. Albaugh, S.Y. Dillen, J.C. Domec, R. Fichot, et al., The challenge of lignocellulosic bioenergy in a water-limited world, Bioscience 63 (2) (2013) 102-117.

[6] D. Binkley, J.L. Stape, M.G. Ryan, Thinking about efficiency of resource use in forests, ForEcolManage $193(1-2)$ (2004) 5-16.

[7] J.J. Landsberg, P.J. Sands, Physiological Ecology of Forest Production Principles, Processes and Models, Academic Press, London, 2011.

[8] M.G.R. Cannell, Physiological basis of wood production: a review, ScandJForRes 4 (1989) 459-490.

[9] S. Linder, Response to water and nutrients in coniferous ecosystems, in: E.D. Schulze, H. Zwolfer (Eds.), Potentials and Limitations of Ecosystem Analysis, Springer-Verlag, Berlin, 1987, pp. 180-202.

[10] J.L. Stape, D. Binkley, M.G. Ryan, S. Fonseca, R.A. Loos, E.N. Takahashi, et al., The Brazilian Eucalyptus Potential Productivity Project: influence of water, nutrients and stand uniformity on wood production, ForEcolManage 259 (2010) $1684-1694$.

[11] J.A. Stanturf, E.D. Vance, T.R. Fox, M. Kirst, Eucalyptus beyond its native range: environmental issues in exotic bioenergy plantations, Int. J. For. Res. 2013 (2013) $1-5$.

[12] R.C. Kellison, R. Lea, P. Marsh, Introduction of Eucalyptus spp. into the United States with special emphasis on the southern United States, Int. J. For. Res. 2013 (2013) 1-9.

[13] T.J. Albaugh, H.L. Allen, P.M. Dougherty, K.H. Johnsen, Long term growth responses of loblolly pine to optimal nutrient and water resource availability, ForEcolManage 192 (1) (2004) 3-19.

[14] J. Bergh, S. Linder, T. Lundmark, B. Elfving, The effect of water and nutrient availability on the productivity of Norway spruce in northern and southern Sweden, ForEcolManage 119 (1) (1999) 51-62.

[15] P. Trichet, D. Loustau, C. Lambrot, S. Linder, Manipulating nutrient and water availability in a maritime pine plantation: effects on growth, production, and biomass allocation at canopy closure, AnnForSci 65 (2008) 814-826.

[16] J. Alvarez, H.L. Allen, T.J. Albaugh, J.L. Stape, B.P. Bullock, C. Song, Factors affecting the growth of radiata pine plantations in Chile, Forestry 86 (2013) $13-36$.

[17] M.L. Benson, B.J. Myers, R.J. Raison, Dynamics of stem growth of Pinus radiata as affected by water and nitrogen supply, ForEcolManage 52 (1-4) (1992)
$117-137$.

[18] J.L. Stape, D. Binkley, M.G. Ryan, Eucalyptus production and the supply, use and efficiency of use of water, light and nitrogen across a geographic gradient in Brazil, ForEcolManage 193 (1-2) (2004) 17-31.

[19] B.E. Ewers, R. Oren, T.J. Albaugh, P.M. Dougherty, Carry-over effects of water and nutrient supply on water use of Pinus taeda, EcolAppl 9 (2) (1999) $513-525$.

[20] G. Goldstein, S.J. Bucci, F.G. Scholz, Why do tree adjust water relations and hydraulic architecture in response to nutrient availability? Tree Physiol. 33 (2013) 238-240.

[21] M.S. Watt, D. Whitehead, E.G. Mason, B. Richardson, M.O. Kimberley, The influence of weed competition for light and water on growth and dry matter partitioning of young Pinus radiata, at a dryland site, ForEcolManage 183 (2003) 363-376.

[22] T.J. Albaugh, J.L. Stape, T.R. Fox, R.A. Rubilar, H.L. Allen, Mid-rotation vegetation control and fertilization response in Pinus taeda and Pinus elliottii across the southeastern United States, SouthJApplFor 36 (1) (2012) 44-53.

[23] D. Binkley, J.L. Stape, W.L. Bauerle, M.G. Ryan, Explaining growth of individual trees: light interception and efficiency of light use by Eucalyptus at four sites in Brazil, ForEcolManage 259 (2010) 1704-1713.

[24] O.C. Campoe, J.L. Stape, T.J. Albaugh, H.L. Allen, T.R. Fox, R.A. Rubilar, et al., Fertilization and irrigation effects on tree level aboveground net primary production, light interception and light use efficiency in a loblolly pine plantation, ForEcolManage 288 (2013) 43-48.

[25] CONAF, Resolución 283, Diario Oficial de la República de Chile, Santiago, Chile 2011, p. 9.

[26] FAO, Global Forest Resources Assessment, FAO Forestry Paper. Rome2010, 2010, p. 378.

[27] R.A. Rubilar, T.J. Albaugh, H.L. Allen, J. Alvarez, T.R. Fox, J.L. Stape, Influences of silvicultural manipulations on above- and belowground biomass accumulations and leaf area in young Pinus radiata plantations, at three contrasting sites in Chile, Forestry 86 (1) (2013) 27-38.

[28] H. Bi, E.M. Birk, J. Turner, M.J. Lambert, V. Jurskis, Converting stem volume to biomass with additivity, bias correction, and confidence bands for two Australian tree species, NZJForSci 31 (3) (2001) 298-319.

[29] H. Gilabert, C. Paci, An assessment of volume-ratio functions for Eucalyptus globulus and E. nitens in Chile, Cien Inv Agr 37 (1) (2010) 5-15.

[30] A. Sadzawka, R. Grez, M.A. Carrasco, M.D.L.L. Mora, Métodos de análisis de tejidos vegetales, Sociedad Chilena de la Ciencia del Suelo, Chile, 2004.

[31] SAS-Institute, SAS Version 9.1 TS, SAS Institute, Inc, Cary, NC, 2002.

[32] G.L. Baskerville, Use of logarithmic regression in the estimation of plant biomass, CanjForRes 2 (1) (1972) 49-53.

[33] J. Brockwell, S.D. Searle, A.C. Jeavons, A. Waayers, Nitrogen Fixation in Acacias: an Untapped Resource for Sustainable Plantations, Farm Forestry and Land Reclamation, ACIAR, Canberra, 2005.

[34] B.M. May, P.M. Attiwill, Nitrogen-fixation by Acacia dealbata and changes in soil properties 5 years after machanical disturbance or slash-burning following timber harvest, ForEcolManage 181 (2003) 339-355.

[35] D.R.C. Tye, D.C. Drake, An exotic Australian Acacia fives more N than a coexisting indigenous Acacia in a South African riparian zone, Plant Ecol. 213 (2) (2012) 251-257.

[36] V.M. Shorrocks, The occurrence and correction of boron deficiency, Plant Soil $193(1-2)(1997) 121-148$.

[37] J.A. Simpson, P. Dart, G. McCourt, Diagnosis of nutrient status of Acacia mangium, in: J.W. Turnbull, H.R. Crompton, K. Pinyopusarerk (Eds.), Recent Developments in acacia Planting, ACIAR, Canberra, 1998, pp. 251-257.

[38] T.S. Judd, P.M. Attiwill, M.A. Adams, Nutrient concentrations in Eucalyptus: a synthesis in relation to differences between taxa, sites and components, in: P.M. Attiwill, M.A. Adams (Eds.), Nutrition of eucalyptus, CSIRO, Collingwood, 1996, pp. 123-153.

[39] J.S. Prado, J. Toro, Silviculture of eucalypt plantations in Chile, in: P.M. Attiwill, M.A. Adams (Eds.), Nutrition of Eucalypts, CSIRO, Collingwood, 1996, pp. 357-370.

[40] H. Marschner, Mineral nutrition of Higher Plants, Academic Press, New York 1986.

[41] J. Turner, M.J. Lambert, Nutrient cycling and forest management, in: P.M. Attiwill, M.A. Adams (Eds.), Nutrition of Eucalypts, CSIRO, Collingwood 1996, pp. 229-248.

[42] T.S. Judd, Simulated nutrient losses due to timber harvesting in highly productive eucalypt forests and plantations, in: P.M. Attiwill, M.A. Adams (Eds.), Nutrition of Eucalypts, CSIRO, Collingwood, 1996, pp. 249-258.

[43] T.R. Fox, Sustained productivity in intensively managed forest plantations, ForEcolManage 138 (2000) 187-202.

[44] D. Binkley, R.F. Fisher, Ecology and Management of Forest Soiils, fourth ed., Wiley-Blackwell, United Kingdom, 2013.

[45] L.T. Bennett, C.J. Weston, P.M. Attiwill, Biomass, nutrient content and growth response to fertilisers of six-year-old Eucalyptus globulus plantations at three contrasting sites in Gippsland, Victoria, Aust. J. Bot. 45 (1) (1997) 103-121.

[46] E. Acuña, J. Cancino, R.A. Rubilar, M. Espinosa, F. Muñoz, Informe fina proyecto Innova Bio Bio $N^{\circ}$ 06-PC S1-33: Desarrollo de protocolos para la producción de biomasa de especies forestales de rápido crecimiento y corta rotación para la generación de bioenergía, Universidad de Concepción-Innova Bio Bio, Concepción, Chile, 2012.

[47] M. Morales, G. Aroca, R.A. Rubilar, E. Acuña, B. Mola-Yudego, S. GonzalezGarcia, Cradle-to-gate life cycle assessment of Eucalyptus globulus short 
rotation plantations in Chile, J. Clean. Prod. 99 (2015) 239-249.

[48] P.J. Smethurst, C. Baillie, M. Cherry, G. Holz, Fertilizer effects on LAI an growth of four Eucalyptus nitens plantations, ForEcolManage 176 (1-3) (2003) $531-542$.

[49] B.R. Maslin, W.W. McDonald, AcaciaSearch: Evaluation of Acacia as a Woody Crop Option for Southern Australia, Rural Industries Research and Developement Corporation, Canberra, 2004, p. 260.

[50] B. Dell, Diagnosis of nutrient deficiencies in eucalypts, in: P.M. Attiwill,
M.A. Adams (Eds.), Nutrition of Eucalyptus, CSIRO, Collingwood, 1996, pp. 417-440.

[51] J.P. Boisier, R. Rondanelli, R.D. Garreaud, F. Muñoz, Anthropogenic and natural contributions to the southeast Pacific precipitation decline and recent megadrought in central Chile, Geophys Res. Lett. (2015) 43.

[52] D.L. Forrester, J. Bauhus, P.K. Khanna, Growth dynamics in a mixed-species plantation of Eucalyptus globulus and Acacia mearnsii, ForEcolManage 193 $(1-2)(2004) 81-95$ 